\title{
ENGLISH PRESENT PARTICIPLES \\ AND GERUNDS FUNCTIONING AS ADVERBIALS AND THEIR TRANSLATIONS INTO CZECH
}

\author{
Renata Šimuinková
}

\begin{abstract}
The paper presents a comparative study of non-finite -ing forms with the aim of justifying their classification into gerunds and present participles. The empirical part focuses on -ing forms functioning as adverbials in contemporary English fiction and their corresponding Czech translations. The study is based on a manually excerpted corpus of works of contemporary English fiction and their translations into Czech. The results have shown present participles are more frequent than gerunds when functioning as adverbials, suggesting functional differences even in the area where they theoretically share a common function. As far as the translations into Czech are concerned, significant differences have been noticed between the two -ing forms, present participles being most commonly translated by means of clauses in a coordinate relation while for gerunds a way of translation which would so significantly prevail has not been identified, but nouns or verbal nouns have been the most common counterparts.
\end{abstract}

\section{Keywords}

non-finite verb phrase, present participle, gerund, translation, condensation, contrastive analysis

\section{Introduction}

Non-finite verb phrases and their functions in English have been drawing linguists' attention for a long time. Apart from this general interest, which seems to be generally more noticeable among Czech than English linguists, possibly because it is an area where Czech and English significantly differ, the motivation for this study has further arisen from two additional sources. First, recent research into non-finite verb phrases both in English and in Czech has shown that the already significant differences are getting even bigger, and thus comparative studies focusing on contemporary language are of importance. In her research into the development of the structure of an English sentence in the last hundred years, Malá $(2013,2015)$ has found out that the frequency of non-finite clauses has been increasing. On the other hand, as has been pointed out by e.g. Dvorák (1983), the system of Czech non-finite forms has been developing in the direction of a lesser complexity, with the participle forms disappearing from active use. Second, a study of students' translations of nonfinite verb phrases conducted two years ago among Czech students in a teacher training programme 
demonstrated that non-finite structures represented a real challenge for learners of English. They often applied word-for-word translations using transgressive forms ('přechodníky' in Czech), which are no longer productive language means, or they used one 'established' way of translation for certain structures regardless of the context not realizing that it may not have been an ideal solution. They generally lacked experience of and opportunities for contrastive work. More information about the research can be found e.g. in Šimůnková (2015).

The findings presented here are part of a study into functions of nonfinite verb forms in contemporary English fiction and their reflections in the corresponding Czech translations. The corpus compiled should, apart from providing quantitative information about the frequencies of the individual nonfinite verb phrases in individual functions, provide contemporary authentic examples which should illustrate and contribute to the understanding of to what extent and how the two languages structure the respective area differently. The present paper discusses -ing forms with the aim of proving that their distinction into gerunds and present participles is justifiable and beneficial, at least when presenting the system of -ing verb phrases to Czech speakers. The empirical part focuses on gerunds and present participles functioning as adverbials, the area where they theoretically share a common function, and it strives to illustrate that significant systemic differences can be seen both between the two functions themselves and mainly between the ways they are translated into Czech, which provides further arguments for the distinction of -ing non-finite verb phrases into the two categories.

\section{Non-finite verb phrases}

Although, as mentioned previously, non-finite verb forms and phrases are well established terms among linguists, upon closer scrutiny, mainly of linguists writing in English, a lack of a detailed and systematic approach to this issue may be observed. It is difficult to find a resource which would provide a complete picture of the system of non-finite verb phrases in English, the functions and grammar of each individual element in the system and the relations and differences between them. Some authors provide only a list of the existing forms without attempting to define or discuss their role in the language in any depth (Leech \& Svartvik 2002, Carter \& McCarthy 2006). Other linguists probe a bit deeper trying to define them and to establish their grammar and functions (Quirk 1985, Biber 1999). The pieces of relevant information are, however, scattered throughout their grammars and it is quite a demanding task for a reader to obtain a complex picture. The same observation has already been made by Granger (1997: 185), who claims that "not only are they (meaning non-finite clauses) insufficiently described, they are also usually scattered across several sections of 
grammar, thus making it very difficult for EFL learners to form an overall picture of the part they play in discourse". Yet, it can be seen that non-finite verb phrases are generally presented as those not functioning as verbs on a syntactic level as they "do not normally occur as the verb phrase of an independent clause" (Quirk 1985: 150) and they "do not contain any specification of tense and modality" (Biber 1999: 99).

The approach of Czech linguists in this area seems to be much more thorough as their aim is often not only to describe the language, but also to discuss the mentioned structural differences with regards to Czech learners of English and this aim requires much more systematic treatment as a basis for contrastive analysis. For example, Dušková (1994: 165) introduces different verb forms in English in the following way:

According to whether the verb form expresses all verb categories or only some of them, the verb forms are divided into finite and non-finite. Finite verb phrases express grammatical concord with a subject in the person and number while nonfinite verb phrases do not distinguish the person and number. As regards other verbal categories, only the system of gender and partly the temporal system are applied in non-finite verb phrases.

For the purpose of this paper, a non-finite phrase is a verb phrase which is not marked for tense and subject-verb concord and does not function as a verb in the sense of sentence elements in an independent clause, but which constitutes the predicate of a non-finite dependant clause.

Having defined non-finite forms for the purpose of this paper, the following paragraph establishes which non-finite verb forms are distinguished in this paper and mainly how they are delimited. There seem to be two non-finite verb forms which are generally accepted: the infinitive and the past participle. These two forms are distinguished in e.g. Quirk (1985), Biber (1999), Leech and Svartvik (2002), Dušková (1994), and they also appear to be defined in the same way there. Additionally, in all the mentioned sources an -ing form is established as a non-finite form; however, its treatment by different authors differs. Some authors (Quirk 1985, Biber 1999, Leech \& Svartvik 2002) speak about -ing clauses, without distinguishing them further. Other authors, e.g. Dušková (1994), establish a special category of gerund. Another problem in the area of -ing forms is how to set boundaries between categories of a noun, deverbal noun, verbal noun and gerund on the one hand and adjective, verbal adjective and present participle on the other as the individual categories seem to be working on a centre-periphery principle rather than on a principle of clearly distinguishable categories. In our paper a distinctive category of gerund is applied and the following section attempts to provide a justification for the decision. 


\section{3 -ing forms}

\subsection{Gerund versus present participle}

The authors who do not distinguish the gerund from the present participle generally offer the following reasons: both the forms belong to the same inflectional category; from the syntactic point of view the structures in which they are used and their functions are the same (Huddleston \& Pullum 2002: 1220-1223); the English gerund does not correspond to the Latin gerund on the basis of which it has been established in English grammar (mainly the modal/ non-modal distinction is not reflected); no such functional difference is applied to the infinitive, so why to apply it to -ing forms (Quirk 1985: 1290)? The reasons mentioned above are now examined one by one and explanations are provided as to why they have been dismissed from our classification. Drawing on the Prague School tradition, in our approach the concept of function was given preference over other criteria and the semantic and morphological potential of -ing forms is identified from the perspective of their function on a higher level of linguistic description (phrase - clause - sentence).

Huddleston and Pullum (2002: 1220) argue that the forms traditionally distinguished as gerunds and participles "belong to a single inflectional category. We call this form the gerund-participle to reflect the fact that it covers the ground of both gerunds and present participles in other languages". Although, on the one hand, this solution can help to illustrate the complexity of -ing forms covering the gradient of functions from fairly nominal to fully verbal, on the other hand, it makes opaque the correspondence between the present and past participle where the functional correspondence is much tighter than between gerund and participle. The mentioned correspondence is even more important in relation to Czech learners of English because both the participle forms are commonly used as Czech transgressives, but since the transgressives are not productively used in Czech any longer, mistakes are often made when these structures (usually nonfinite clauses) are translated.

The second argument used is that "even from a purely syntactic point of view no viable distinction can be drawn between the forms" (Huddleson \& Pullum 2002: 1220). Immediately in the following paragraph the authors, however, admit that in structures where a subject of the non-finite clause is expressed, it will have a different form if used with a gerund or present participle. They then conclude that this distinction applies only to these specific structures which are not numerous and add that the "contract is handled by the distinction between complement and non-complement gerund-participle" (ibid.: 1221). It is clear that there is a difference in function which needs to be solved somehow and 
their solution differs from the more traditional one only in the criteria chosen: complement/non-complement versus nominal/adjectival function and the choice of the authors is logical since they have decided to refuse the traditional classification of clauses and infinitivals and sentence elements based on parts of speech. Quirk's (1985: 1292) argument that "no analogous categorical distinction was made between the infinitive" is strong and holds also in the functional approach described here, as the infinitive can function both nominally and adverbially. On the other hand, this can also be applied to the gerund, but no claims of nominal character of participles have come to light. So taking a slightly different standpoint, Quirk's argument can even be used to support the distinction between the two forms to be made as it further points out the gradient between a noun, verbal noun and gerund, on the one hand, and adjective, verbal adjective and present participle, on the other, and it is then only the question of which correlations a linguist considers more important for a clear presentation of a language system. In addition, Quirk et al. (1985) use the terms gerund and participle themselves, and although they discuss the gradient from deverbal nouns via verbal nouns to participles, in the particular section of the book where it is discussed, they provide not only an example of an -ing form functioning as a clear noun (used with a determiner and in the plural), but also an -ing form functioning as an adjective proper is presented in a different section of the book (Subsection 17.98) physically demonstrating the distance between -ing forms functioning as nouns and adjectives. They therefore in their way apply the noun/ adjective distinction which we consider important as it enables the verification of the correspondence between present and past participle. This is important for Czech learners as has been and will be further demonstrated.

Having discussed some of the arguments against the classification of -ing forms into gerunds and present participles, the counter approach is now presented. One strong argument, suggested e.g. by Dušková (1994: 268-269), is that gerunds and participles, when in position in front of a noun, are distinguished by intonation and stress structure. If a gerund is used, it is with a falling intonation curve and one main stress and a pitch at the beginning (melting point) while for a present participle the intonation curve has two pitches and there are two stresses, one on each word (e.g. melting snow). Stress often works as a distinctive and reliable means distinguishing language categories. The second argument relates to the function of participle forms as transgressives. Dušková (1994: 583) writes that the transgressive is often counted among subject complements, but it also has some features of adverbials. Dušková thus, when discussing functions of participles, retains the function of the transgressive as a separate category and examines both present and past participles together to clearly show their analogous functions. 
A typical example of an -ing form with this function might be She stopped for a moment, thinking of what to do next. Linguists who do not work with this functional category have to class this function in an alternative way. Quirk et al. (1985) treat functions of non-finite clauses together with finite ones and are rather brief in discussing the whole issue. Regarding non-finite participle clauses functioning as transgressives, the authors seem to be dealing with only one type, structures such as No further discussion arising, the meeting was brought to a close, or Lunch finished, the guests retired to the lounge, where the non-finite clause stands at the beginning of a sentence, and the authors count these among adverbials. We have not managed to verify how they would class the sentence She stopped for a moment, thinking of what to do next, as we have not found a similar structure categorized in his book. It is worth noticing, however, that in the first structure, the authors naturally put together past and present participles as their function, as we have pointed out before, is analogous. Janigová (2008), who in her book draws a lot on Quirk et al. (1985), provides examples of participles functioning as subject complements, which in our classification we would also consider subject complements, and examples of adverbial functions which we, together with Dušková, would classify as transgressives. The treatment offered by Huddleson and Pullum (2002) is completely different as they refused the approach of classifying clauses based on their function as sentence elements, but even in their approach no distinct function of the transgressive is established and also the functional correspondence between present and past participle is rather concealed or at least not pointed out. Huddleson and Pullum's attitude is commented on by de Smet, an author of an extensive study of present participles and of -ing clauses in general. He claims (2010: 1188) that a syntactic category in general has at least four characteristics and that "the fourth characteristic is one which Huddleson and Pullum do not recognize when collapsing the categories of gerunds and participles". In another article of his (2011: 477), de Smet summarises his opinion on the matter: "the distributionally defined categories of participles and gerunds remain relevant generalizations to language users, even though they are at times lowly, salient and violable, competing with a more unified analysis of -ing clauses".

To conclude, we believe that none of the authors rejecting the classification of -ing forms into gerunds and participles have been able to defend their standpoint convincingly or they were at least not able to demonstrate in what way such a classification might distort the perception of the structure. We further believe, for the reasons provided above, that from the standpoint of a Czech user of English, the classification is beneficial as it enables the illustration of a clear parallel between present and past participles as distinct from gerunds, which then 
enables the verification of the function of the transgressive as a common function of both the participle forms, which is also a clear function generally recognized in Czech. This established correspondence should subsequently, by means of contrastive analysis such as the one described in the empirical part of this paper, help students to understand the differences in the ways the function is expressed in the two languages and thus prevent them from making translation mistakes. This section has also explained why we speak about gerunds and participles functioning as adverbials, although in the case of participles we actually mean 'transgressives'. It is an approach applied by a number of linguists as shown above and we believe it might help to prove that even though some linguists consider the functions to be the same in English, the translation solutions in Czech are different for the two forms, which justifies the distinction to be made at least for Czech learners of English.

\subsection{The gradient between gerunds - nouns and participles - adjectives}

Having explained our decision to distinguish between gerunds and participles and provided the grounds for it in the previous section, it is now also necessary to distinguish between the individual nominal and adjectival categories of -ing forms, or in other words, to distinguish the individual categories on the scale from a noun to a gerund, on the one hand, and an adjective and a present participle, on the other. For this purpose, the procedure suggested and discussed in detail by Janigová (2008) has been adopted. Her solution, however, had to be partly adjusted as, while she provides a detailed and well-argued classification of the nominal scale, she completely leaves out the category of an -ing form functioning as an adjective. She includes this option later in the discussion, but only as an additional comment. Since, however, for our approach a consistent distinction is important, the function of an adjective is included among the main functions of -ing clauses. We also have to note that in our classification we leave out two functions of -ing forms, namely the cases when the -ing form is part of a complex verb phrase and when it functions as a preposition or a conjunction. In the first case the -ing form does not function as an independent lexeme and thus it is beyond the scope of our interest and in the second the function represents a small set of fixed phrases which can be considered as exceptions rather than an integral part of the system.

Having applied the adjustments above, the updated classification based on Janigová (2008: 68) leaves us with the following categories of -ing forms distinguished in our study:

1. deverbal nouns

2. verbal nouns 
3. gerunds

4. adjectives

5. participles

We have not attempted to provide any systematic list of criteria distinguishing the individual -ing forms. Criteria are, however, provided to be applied to our corpus to differentiate between the excerpted forms. For our purposes, a deverbal noun is a regular countable noun which can be used in the plural and with an indefinite article, and a verbal noun is one which can be used with the definite article and demonstratives (e.g. this, that). These two forms are purely nominal forms. On the other hand, gerunds and participles are forms often described as a mixture of nominal and verbal properties. To distinguish between these two categories, Janigová's (2008:18) criteria are applied, claiming that the gerund has three nominal features (premodification by a genitive case, determiners no and any, introduced by a preposition) and five verbal features (objective/common case, adverbial modification, object complementation, voice and perfect/ nonperfect contrast. The present participle, on the other hand, does not have any of the nominal properties of the gerund, but has two additional verbal features (it can be introduced by a conjunction and in addition to perfect/nonperfect contrast it also distinguishes progressive/nonprogressive contrast). To conclude, although gerunds and participles have several features in common, only the gerund can be used with the genitive case, no and any, and introduced by a preposition, while only the participle can be introduced by a conjunction and express progressive/ nonprogressive distinction. An adjective is then distinguished from the present participle by the fact that it can be graded and premodified by very.

\subsection{Functions of gerunds and present participles}

In the following section the repertory of syntactic functions performed by gerunds and participles is discussed. The functions are delimited based on Quirk et al. (1985), who distinguish three basic functions: determination, modification and complementation. As -ing forms do not function as determiners, this function is not considered any further. In our approach, modification is recognised as operating only on the phrasal level and thus the use of an -ing form in this function does not result in the multiple status of the whole sentence. In this function, both gerunds and participles can function as premodifiers and postmodifiers. Quirk et al. (1985: 65) understand complementation as "the function of a part of a phrase or clause which follows a word, and completes the specification of a meaning relationship which that word implies". We can thus speak about complementation of nouns, adjectives, adverbs or prepositions and on the level of a sentence structure also about complementation of a verb where we can 
distinguish functions of an object, complement and adverbial. In the corpus, therefore, the following functions of gerunds and participles were distinguished:

Gerund: subject, subject complement, object (with or without a preposition), object complement, adjective complement, adverbial, and modification (pre- and postmodification).

Present participle: subject complement, object complement, transgressive (which for the reasons above in this paper are referred to as an adverbial function), and modification (pre- and postmodification). The current paper, however, focusses only on the -ing phrases functioning as adverbials.

\section{Empirical part}

\subsection{Corpus compilation}

With regards to the developments both in English and Czech discussed, it was crucial to use sources as contemporary as possible. Therefore, only books not older than 15 years were selected. To ensure the quality of translation, only translations which were awarded recognized translation prizes were included in the corpus, e.g. the Josef Jungmann Prize or Award for Creativity (Tvưrčí cena). Out of each of the four books actually used (listed in References) 200 non-finite verb phrases were excerpted (as it has been explained, the analysis included here is a part of a complex study of non-finite verb forms, so the number for each book also includes infinitives and past participles). Each excerpt always represented a whole sentence to allow for subsequent qualitative discussions. The excerpted non-finite forms were also tagged so that filtering according to particular criteria was then possible. The following pieces of information were marked: author/book, type of non-finite forms (passive and perfect forms of individual distinguished types (see above) were marked separately) and method of translation into Czech. The potential ways of translation were investigated in literature prior to the compilation of the corpus to enable these categories to be marked as well so that the corpus could be also filtered according to particular translation solutions. This preliminary theoretical classification was then adjusted based on the actual translations appearing in the corpus (however, only slight adjustments were needed and only in the area of translations of present participle forms which are not further focused on in this paper).

\subsection{Analysis of the excerpts}

The whole corpus used for the study contained 800 non-finite phrases and their corresponding translations. For the present study, however, which is a contrastive analysis of -ing clauses functioning as adverbials, only the specific 
forms were dealt with: gerunds functioning as adverbials and present participles functioning as transgressives. Although it might seem that we have selected two different functions, it has already been explained that not many authors actually distinguish between the function of a transgressive and an adverbial (e.g. Quirk et al. 1985, Janigová 2008). Our analysis includes both non-finite adverbial clauses with an expressed relation to the main clause as well as supplementive non-finite clauses. Our interest in these functions and their translations can be justified by a number of linguists who have recognised their complexity and thus potential misinterpretations. Cho and Park (2015: 5), for example, claim that "what makes non-native speakers use fewer participle clauses, in particular supplementive participle clauses or detached participles, is that they are interpreted in diverse ways due to the absence of a subordinator in the participle clause". In the same manner Martinéz (2015: 88) points out that "these clauses function as adverbial complements, but their adverbial meanings may be as varied and frequently overlapping as temporal, concessive, causal, and conditional, as well as result, concurrency in time, manner or reason," and Dontcheva-Navratilova (2005: 44) expresses the same, only in different words, "the relationship between a supplementive clause and the main clause is considered to be loose and typically left indeterminate".

As regards the translation solutions in Czech, the following ones were distinguished, based on theory and practical findings from the corpus:

a) main clause (Main)

b) subordinate clause (Sub)

c) verbal noun $(\mathrm{VN})$

d) $\operatorname{noun}(\mathrm{N})$

e) adjective (A)

f) transgressive (Trans)

g) no equivalent (NoCS)

h) a different solution (Other)

\section{Discussion of the results}

In order to provide a complete picture and to place the analysis of the particular -ing verb phrases focused on in this paper into the context of the whole study, first the overall distribution of all non-finite verb forms found in the corpus is presented. They are summarised in the table below, where the first column represents the particular books and the following columns the absolute quantities of the individual forms found in each individual book. 


\begin{tabular}{|l|c|c|c|c|}
\hline BOOK & INFINITIVE & GERUND & $\begin{array}{c}\text { PRESENT } \\
\text { PARTICIPLE }\end{array}$ & $\begin{array}{c}\text { PAST } \\
\text { PARTICIPLE }\end{array}$ \\
\hline Enrig. & 54 & 20 & 90 & 36 \\
\hline Hard. & 72 & 18 & 62 & 48 \\
\hline Barn. & 58 & 54 & 58 & 30 \\
\hline Mitch. & 87 & 30 & 34 & 49 \\
\hline
\end{tabular}

Table 1: Quantitative summary

Focusing further only on gerunds and the present participle, the most surprising information gained from this overall summary has been the fact that in the whole corpus only a few cases of other than the basic form of gerunds and participles have been found, namely one passive form of a gerund and one passive form of a participle, both in Barnes, and two perfect forms of a participle, both found in Harding. Only one of the four forms has been used in the function the paper focuses on. We expected the more complex forms to be more frequent, so we sought some explanations. The first obvious source to consult this finding was the Longman Grammar of Spoken and Written English, which is a grammar based on a corpus providing information on frequencies of various grammatical forms. However, as was discussed earlier, non-finite forms as such have not been given any really systematic attention and as regards the perfect forms themselves, only their mere existence was mentioned, and although a number of examples of non-finite forms are provided, the perfect forms are not included. The best source to check would naturally be a corpus. This will, however, be a subject-matter of future investigations.

The overall quantitative data also suggest that gerunds tend to be less frequent than present participles. This applied to all the four books, but in two of them the quantities were almost balanced (Barnes and Harding), while in the other two, the difference was considerable, in Enright reaching the ratio of 20/90 meaning that gerunds represented only ten per cent of all the 200 non-finite forms excerpted in Enright.

The following section focuses only on gerunds and participles functioning as adverbials and the corresponding translations into Czech. First, the quantitative data separately for each book is provided and then the solutions applied are discussed and certain translation tendencies are searched for. In order not to lose the idea of proportion, the number before the slash represents the quantity for the particular book and the number after the slash the total quantity regarding the particular category in the corpus. 
Renata Š IMƯNKOVÁ

\begin{tabular}{|c|c|c|c|}
\hline \multicolumn{4}{|l|}{ Enright } \\
\hline Gerund translated as & $5 / 22$ & Pres. participle translated as & $50 / 123$ \\
\hline Main & $0 / 3$ & Main & $43 / 85$ \\
\hline Sub & $3 / 7$ & Sub & $0 / 10$ \\
\hline $\mathrm{VN}$ & $0 / 4$ & $\mathrm{VN}$ & $0 / 5$ \\
\hline $\mathrm{N}$ & $0 / 2$ & $\mathrm{~N}$ & $0 / 1$ \\
\hline NoCS & $0 / 4$ & NoCS & $3 / 5$ \\
\hline \multirow[t]{2}{*}{ Other } & $2 / 2$ & Other & $1 / 4$ \\
\hline & & A & 3 \\
\hline
\end{tabular}

Table 2: Enright

\begin{tabular}{|l|l|l|l|}
\hline Harding & $\mathbf{3 / 2 2}$ & Pres. participle translated as & $\mathbf{3 7 / 1 2 3}$ \\
\hline Gerund translated as & $0 / 3$ & Main & $15 / 85$ \\
\hline Main & $1 / 7$ & Sub & $6 / 10$ \\
\hline Sub & $2 / 4$ & VN & $3 / 5$ \\
\hline VN & $0 / 2$ & N & $1 / 1$ \\
\hline N & $0 / 4$ & NoCS & $2 / 5$ \\
\hline NoCS & & Other & $0 / 4$ \\
\hline Other & & VA & $3 / 3$ \\
\hline & & Infinitive & $7 / 7$ \\
\hline
\end{tabular}

Table 3: Harding 


\begin{tabular}{|c|c|c|c|}
\hline \multicolumn{4}{|l|}{ Barnes } \\
\hline Gerund translated as & $10 / 22$ & Pres. participle translated as & $25 / 123$ \\
\hline Main & $3 / 3$ & Main & $18 / 85$ \\
\hline Sub & $3 / 7$ & Sub & $2 / 10$ \\
\hline $\mathrm{VN}$ & $0 / 4$ & $\mathrm{VN}$ & $2 / 5$ \\
\hline $\mathrm{N}$ & $0 / 2$ & $\mathrm{~N}$ & $0 / 1$ \\
\hline NoCS & $4 / 4$ & NoCS & $0 / 5$ \\
\hline Other & & Other & $3 / 4$ \\
\hline
\end{tabular}

Table 4: Barnes

\begin{tabular}{|c|c|c|c|}
\hline \multicolumn{4}{|l|}{ Mitchell } \\
\hline Gerund translated as & $4 / 22$ & Pres. participle translated as & $11 / 123$ \\
\hline Main & $0 / 3$ & Main & $9 / 85$ \\
\hline Sub & $0 / 7$ & Sub & $2 / 10$ \\
\hline VN & $2 / 4$ & $\mathrm{VN}$ & $0 / 5$ \\
\hline $\mathrm{N}$ & $2 / 2$ & $\mathrm{~N}$ & $0 / 1$ \\
\hline NoCS & $0 / 4$ & NoCS & $0 / 5$ \\
\hline Other & & Other & $0 / 4$ \\
\hline
\end{tabular}

Table 5: Mitchell

From the data above, it is obvious that participles were more common in the function of adverbials (transgressives) than gerunds, ranging from three to 22 per cent for gerunds and 32 to 97 per cent for present participles. The biggest difference, however, can be seen in the ways these forms were translated into Czech. While for the participle forms by far the most frequent way of translation was by a clause, mainly a main clause (similar results were arrived at by e.g. Malá \& Šaldová (2015) in their study based on the parallel corpus Intercorp), for gerunds no particular translation solution which would significantly prevail was found, but altogether there were only three cases of translation by a main clause and seven by a subordinate clause, while the most frequent solutions were by nouns or verbal nouns. 
As the translation by means of a subordinate clause represents the area where the translation solutions of the two studied forms overlap the most, they are studied in greater detail. Gerunds in this function have always been used after a preposition, which clearly expressed the logical relation between the two clauses and the same relation has then been expressed by a corresponding conjunction in Czech. In this respect the translation solutions used seemed almost mechanical (Examples 1 and 2). One might argue that before could theoretically be also classified as a conjuction, which would be possible in the approach of a common -ing form. Classifying making as a gerund in Example 2 not only clearly places it in parallel with Example 1, but it also enables a straightforward classification of being as a preposition.

(1) So I am in a rage with every single one of my brothers and sisters, including Stevie, long dead, and Midge, recently dead, and I am boiling mad with Liam for being dead too, just now, when I need him most.

A tak jsem vzteky bez sebe na jednoho každého ze svých bratrů a sester včetně Stevieho, co už je kolik let po smrti, a Midge, která umřela nedávno, zuř́m i na Liama za to, že také on je mrtvý, právě ted', když ho potřebuji. (Enright)

(2) Where did that come from, I asked myself, before making some half-heartedly imitative gesture of piety, attended by furtive squinting through the fingers.

"Kde se tohle vi̊bec vzalo?" ptal jsem se sám sebe, než jsem vlažnè napodobil jakési zbožné gesto a přitom nenápadně mžoural skrz prsty. (Barnes)

With participles, as discussed in 4.2 , the connection between the two clauses is usually not expressed explicitly, but it is either clearly suggested by the context, as in Example 3, where it would be difficult to think about another logical relation between the two clauses, or it potentially allows more interpretations as in Example 4. The choice of the relative clause in the translation rather than an adverbial clause, which would theoretically be also possible, could have been caused by the effort to retain the vagueness of the original participial clause. This would be fully in accord with one of Malá and Šaldová's (2015: 251) conclusions that translators really feel the importance of "the possibility of keeping this semantic relation inexplicit".

(3) She sorted through both very quickly, knowing exactly what she wanted and what was to be left for - or at least with - the hospital.

Obojí jen zběžně prohrábla, protože věděla naprosto přesně, co si chce nechat a co ponechá v nemocnici - nebo prostě v nemocnici. (Barnes)

(4) Next door, with a roaring fire nine months of the year, is the housekeeper's sitting room, where you may find Mrs Grouse either armchaired and sewing or desked with a puzzlery of papers, trying, as she says, to 'make head nor tail' of things and - what seems to me contradictory - to make their ends meet. 
Vedlejši místnost, kde devět měsícù v roce burácí oheň, je světnice hospodyně a najdeme zde pani Grouseovou bud' ukreslenou nad šitím, nebo ustolenou nad nechápárnou papírů, v nichž se, jak ř́kává, snaži "najít hlavu a patu” a-což se mi zdá podivné - zjistit, která z nich dala a která má dáti. (Harding)

Three cases of gerund were also translated by means of a main clause, all of them used by the same translator (Barnes). Even in these cases (as in fact in all the cases where the gerund functioned as an adverbial), the gerund was always preceded by a preposition (e.g. without in Example 5), and in all the three translations a conjunction aniž was used, which, although belonging among coordinate conjunctions, can also be seen as expressing the adverbial meaning of manner.

I asked my brother, who has taught philosophy at Oxford, Geneva and the Sorbonne, what he thought of such a statement, without revealing that it was my own.

Zeptal jsem se svého bratra, který učil filozofii na Oxfordu, v Ženevě a na Sorbonně, co si o takovém výroku myslí, aniž bych prozradil, že je vlastně můj. (Barnes)

Regarding other ways of translating gerunds, nouns and verbal nouns were used, which was expected. The remaining options represented special cases where an unexpected solution was applied or where the gerund was not translated at all. These cases are discussed towards the end of this section (Example 11) together with participle forms translated in the same way for the purpose of comparison.

It has already been mentioned that present participles were most frequently translated by means of a main clause. Among these solutions, the most common one was by means of two clauses connected by just a comma (Example 7) or a coordinating conjunction and (Examples 6 and 7). These translation solutions and the fact they represented the most frequently applied solutions are fully in accord with Malá and Šaldová's (2015: 251) findings.

(6) 'Beg pardon?'we would shout satirically at one another, cupping hands to ears.

"Prosím," řvali jsme jizlivě jeden na druhého a přikládali si dlaně $k$ uchu. (Barnes)

(7) I shake out my hand, and then my arm, and when the kettle is filled and plugged in, I take off my coat, pulling the wet sleeve inside out and slapping it in the air. Zatřesu rukou, pak celou paží, a když je konvice plná a zapnutá do elektřiny, sundám si kabát, obrátím mokrý rukáv naruby a pleskám s ním ve vzduchu. (Enright)

Another common form was a main clause introduced by a coordinating conjunction other than and (takže in Example 8 and nebot' in Example 9). In 
some cases, a connective (a conjunction or adverb) was also used in an original English clause which explicitly expressed the logical relation and then the translation just did the same. In other cases, the logical relation between the two clauses was added only in Czech by the translator where it was necessary to use a clause as a translation counterpart. The fact that in non-finite clauses the relation does not have to be (and generally is not) expressed can be illustrated in Example 8, which, even if the conjunction (thus) in the English original was omitted, still could be translated in the same way.

She lay in a small, clean room with a cross on the wall; she was indeed on a trolley, with the back of her head towards me as I went in, thus avoiding an instant face-to-face.

Nacházela se $v$ čisté mistnůstce s křižem na zdi. Ležela skutečně na pojizdném voziku, a když jsem vešel, mèla odvrácenou hlavu, takže okamžitému setkání tváři v tvár jsme se vyhnuli. (Barnes)

(9) I had no fixed objection to this, being, as I was, not much younger than Juliet when she got herself romanced, but young Van Hoosier was no Romeo.

Neměla jsem žádných zásadnich námitek, nebot’ jsem nebyla o mnoho mladší než Julie, když milostnila, ale mladý Van Hoosier nebyl žádný Romeo. (Harding)

Participles functioning as transgressives were also occasionally translated by infinitives (Example 10), which were also solutions found by Hornová (1983: 25 ) in her study. Both in our analysis and Hornová's analysis these translations were really rare and this might be the reason why they were not mentioned in Malá and Šaldová (2015: 240). As translations by the infinitive were so scarce, it is difficult to try to make any assumptions about when they are applied, but they at least seem to suggest that an element of modality is often involved.

He was happy enough scampering up and down the ladders and climbing the shelves or hiding behind the drapes, or else he would play outside; you could trust him, even at that early age, to avoid the lake, or Mrs Grouse's prying.

$K$ radosti mu stačilo dovádět na žebřicich, šplhat po regálech a schovávat se za závěsy, anebo si hrál sám venku - třebaže byl malý, dalo se mu věritit, že se vyhne jezeru i slídivému zraku pani Grousové. (Harding)

The last areas of interest are the cases where both gerunds (Example 11) and participles were not translated into Czech at all. This solution appeared mainly in situations where the -ing form expressed an activity or a state obvious from the context or even represented its attendant circumstances, e.g. the state of being a communist can be labelled just as a communist. Alternatively, the activity in question was expressed by a different means, e.g. a noun ( $v$ rukou) (Example 12), thus leaving out the particular verb and just describing the concept of carrying which usually involves the hand. 
(11) By the time I knew her, in the 1950s, she had progressed to being a communist. V padesátých letech, tedy $v$ dobé, kdy jsem ji znal, se už vyvinula v komunistku. (Barnes)

(12) A maid came out of the back kitchen carrying tea on a tray. Zezadu z kuchyně vyšla služebná, v rukou podnos se svačinou. (Enright)

\section{Conclusion}

As far as the approach to the classification of non-finite -ing verb forms is concerned, no convincing arguments against them being distinguished into gerunds and present participles have been found and even some authors claiming such distinction to be minimally unnecessary, do distinguish between the two predominant functions (nominal and adjectival). On the other hand, linguists (mainly Czech ones), working with distinctive categories of gerunds and present participles provide support for such a classification being beneficial as it enables the depiction of a clear parallel between present and past participles as distinct from gerunds, which then enables the verification of the function of the transgressive as a common function of both the participle forms, which is also a clear function generally recognized in Czech.

The short insight into gerunds and participles functioning as adverbials and the ways in which they are translated into Czech has brought the following results. As far as the absolute quantities as they appeared in the corpus are concerned, present participles are more frequently used than gerunds, in one of the sources the difference reaching the ratio of one to 4.5. There were, however, sources where the ratio was almost balanced ( 1 to 0.7$)$; thus it seems that the choice of the individual non-finite forms is to a certain extent dependant on the style of a book or the personal style of an author. This prevalence of present participles also applies to the frequencies of -ing forms functioning as adverbials in each individual book, ranging from 13 per cent to 22 per cent for gerunds and 32 per cent to 97 per cent for present participles. As in this function participles were significantly more frequently used than gerunds in all the four sources, it can be assumed that unlike the first case, this one concerns the question of the system, the function of adverbials being much more closely connected with participles than gerunds and thus suggesting the functional difference of the two forms even in the area where they theoretically share a common function.

As far as translations into Czech are concerned, quite clear-cut differences can be seen between the two -ing forms, supporting our claim even further. While for the participle forms by far the most frequent method of translation was by a clause (mainly main clause), for gerunds no particular translation solution which would significantly prevail was found, but altogether there were only three cases 
of translation by a main clause and seven by a subordinate clause, while the most frequent solutions were by nouns or verbal nouns. Our findings, at least partially (in the area of participles), correspond to the findings by Hornová (1983), who studied translations of -ing forms, not distinguishing gerunds from participles, in clauses where the -ing forms expressed attendant circumstances of the main action expressed in English by finite verbs. When her examples are compared with ours, it is apparent that she actually analyses -ing forms functioning as adverbials and her general results correspond to ours. The only significant difference is that in her corpus, although not very frequent, -ing forms were also translated by means of Czech transgressives, a solution which did not appear in our corpus at all. This could serve as further evidence of transgressives disappearing from Czech as her sources were older (the 1960s). The results therefore provided a further reason (apart from that already discussed in Section 3.1 hereof) for distinguishing -ing forms into gerunds and participles. It is namely the fact that there is a significant difference in translations of gerunds and present participles used in the same or very similar syntactic function. Last but not least, the corpus has also provided an overview of contemporary translation solutions corresponding to -ing forms which can and should be used for teaching purposes and among other things, for the illustration of the criteria based on which gerunds and present participles are distinguished.

\section{Acknowledgements}

This research has been supported by the Student Grant Competition of FP TUL, SGS 21169.

\section{References}

Biber, D., Johansson, S., Leech, G., Conrad, S. and Finegan, E. (1999) Longman Grammar of Spoken and Written English. Harlow: Longman.

Carter, R. and McCarthy, M. (2006) Cambridge Grammar of English. Cambridge: Cambridge University Press.

de Smet, H. (2010) 'English -ing-clauses and their problems: The structure of grammatical categories.' Linguistics 48(6), 1153-1193.

de Smet, H. and Heyvaert, L. (2011) 'The meaning of the English present participle.' English Language and Linguistics 15(3), 473-508.

Dontcheva-Navratilova, O. (2005) 'Supplementive clausses in resolutions.' Theory and Practice in English Studies 3: Proceedings from the Eighth Conference of British, American and Canadian Studies. Brno: Masarykova univerzita. 43-52.

Dušková, L. (1994) Mluvnice současné angličtiny na pozadí češtiny. Praha: Academia.

Dvořák, E. (1983) ‘Ke kodifikaci pravidel uživáni přechodníků. Naše řeč 66(4), 180-192.

Granger, S. (1997) 'On identifying the syntactic and discourse features of participle clauses in academic English: Native and non-native writers compared.' In: Aarts, J., de Mönnink, I. and Wekker, H. (eds) Studies in English Language and Teaching. Rodopi: Amsterdam and Atlanta. 185-197. 
Huddleson, R. and Pullum, G. K. (2002) The Cambridge Grammar of the English Language. Cambridge: Cambridge University Press.

Hornová, L. (1983) Poznámka k funkci a překladu anglických -ing tvarů jako větných kondenzorů.' Philologica 49, 21-32.

Janigová, S. (2008) Syntax of -ing Forms in Legal English. Bern: Peter Lang.

Leech, G. and Svartvik, J. (2002) A Communicative Grammar of English. London: Longman.

Malá, M. (2013) 'Notes on norms and usage of finite/non-finite predication in written English.' Brno Studies in English 39(1), 27-40.

Malá, M. (2015) 'Changing clause types in written English.’ In: Trušník, R., Bell, G. J. and Němčoková, K. (eds) From Theory to Practice 2013: Proceedings of the Fifth International Conference on Anglophone Studies. Zlín: Univerzita Tomáše Bati. 107-117.

Malá, M. and Šaldová, P. (2015) 'English non-finite participial clauses as seen through their Czech counterparts.' Nordic Journal of English Studies 14(1), 232-257.

Martinéz, M. (2015) '-ING supplementive clauses and discourse prominence in literary journalism.' Journal of English Studies 13, 83-108.

Park, J. and Cho, D. W. (2015) 'Supplementive participle clauses in science journal papers by Korean graduate students: A corpus-based study for pedagogical purposes.' The Journal of Asia TEFL 12, 1-36.

Quirk, R., Greenbaum, S., Leech, G. and Svartvik, J. (1985) A Comprehensive Grammar of the English Language. London and New York: Longman.

Šimůnková, R. (2015) 'Non-finite verb phrases in student translations.' ACC Journal, Issue C, 76-84.

\section{Sources}

Harding, J. (2010) Florence and Giles. London: Blue Door.

Harding, J. (2012) Florence a Giles. Translated by Čeněk Matocha. Praha: Plus.

Barnes, J. (2009) Nothing to Be Frightened of. London: Vintage Books.

Barnes, J. (2009) Žádný diovod k obavám. Translated by Petr Fantys. Praha: Odeon.

Enright, A. (2007) The Gathering. London: Jonathan Cape.

Enright, A. (2009) Shledání. Translated by Dominika Křest’anová. Praha: Odeon.

Mitchell, D. (2011) The Thousand Autumns of Jacob de Zoet. London: Sceptre.

Mitchell, D. (2013) Tisíc podzimů Jacoba de Zoeta. Translated by Petra Diestlerová. Praha: Mladá fronta.

Renata Šimůnková is a lecturer and a teacher trainer at the English Department of the Faculty of Science, Humanities and Education of the Technical University of Liberec. She specializes in linguistics and obtained her Ph.D. from Charles University, Prague in 2009. Her recent research focuses on language transfer and translation studies.

Address: Mgr. Renata Šimůnková, Ph.D., Department of English Language, Faculty of Science, Humanities and Education, Technical University of Liberec, Komenského 314/2, 460 05, Liberec 5, Czech Republic. [e-mail: Renata. simunkova@tul.cz] 